\title{
Peertechz
}

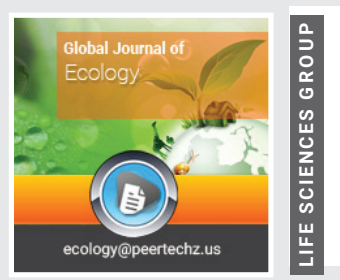

\section{Analysis of risk level at oil production on the shelf of the Caspian Sea}

\section{MZH Nurushev*, MD Diarov² and A Nurusheva ${ }^{1}$}

'Doctor of Biological Sciences, Academician of the Russian Academy of Natural Sciences (RANS), Professor of the Eurasian National University, L.N. Gumilev, st. Kenesary 52 square meters, $380 \mathrm{~g}$. Astana, Kazakhstan

${ }^{2}$ Academician of NAS of RK, Doctor of Geological and Mineralogical Sciences, Institute of Oil and Gas, Atyrau Satpaev 15a sq, Kazakhstan
Received: 19 July, 2017

Accepted: 05 October, 2021

Published: 06 October, 2021

*Corresponding author: MZH Nurushev, Doctor of Biological Sciences, Academician of the Russian Academy of Natural Sciences (RANS), Professor of the Eurasian National University, L.N. Gumilev, st. Kenesary 52 square meters, 380 g. Astana, Kazakhstan, Tel: +7 701-2407458; 87172-996944; E-mail: Nuryshev@mail.ru

Keywords: Caspian Sea; Emissions; Catastrophic; Situation model; Tenghiz; Kashagan

Copyright: @ 2021 Nurushev MZH, et al. This is an open-access article distributed under the terms of the Creative Commons Attribution License, which permits unrestricted use, distribution, and reproduction in any medium, provided the original author and source are credited.

https://www.peertechzpublications.com

\section{Abstract}

The authors considered the rational reasons of effective measures for prevention and liquidation of catastrophic of emission of oil and gas in case of production of oil and gas in the Kazakhstani sector of the Caspian Sea. The comparative analysis with the accident on the Gulf of Mexico (USA) is carried out.

Scientific substantiation of effective measures to prevent and to eliminate oil and gas emissions catastrophe on the Kazakhstani sector of the Caspian Sea is carried out. Currently, Kazakhstan produces 1.6 million barrels a day, which allows us to be among the world's top twenty oil producers. In the next 15 years we plan to double these figures - we have a new field in Tenghiz, Kashagan. The USA's companies such as ExxonMobil, Chevron want to continue to invest in this area.

\section{Introduction}

Emergency oil spill in the Caspian Sea can cause catastrophic dam-age to flora and fauna of the sea. As a result, the intensification of oil operations on the shelf of the Northern Caspian Sea brings to the task of risk assessment plan for the defeat of biota with accidental oil spills [1-4].

At the explosion on the drilling platform of the "British Petroleum" company in the Gulf of Mexico, 5 million barrels or 795,000 tons of oil have been released into the atmosphere and the aquatic environment. Emission speed reached $200 \mathrm{~km}$ / hour, the temperature to $400{ }^{\circ} \mathrm{C}$. The pressure of 8 tons was per square kilometer, which killed dolphins and whales. The populations of crab, oysters and shrimp disappeared for five years. Oil fell in the Atlantic Ocean and the Gulf Stream. All the maritime community has suffered in the Gulf of Mexico, including the seabed.

The first catastrophic oil and gas emissions to the atmosphere area occurred in Kazakhstan in 1985 during the development of the Tengiz oil field. The accident was eliminated within 398 days. Thus the flame height reached $300 \mathrm{~m}$, a diameter of $50 \mathrm{~m}$, air heated in the wellsite to $1500{ }^{\circ} \mathrm{C}$, the soil around the well site to $440^{\circ} \mathrm{C}$. It spilled 3.4 million tons of oil, 1.7 billion cubic meters of flammable gases, including 516, 000 tons of $\mathrm{H}_{2} \mathrm{~S}$ (or 1.0 million $\mathrm{SO}_{2}$ ), 850 tons of mercaptans (highly toxic chemicals), $1.0 \mathrm{mln}$ tons of unburned hydrocarbons and 900,000 tons of soot. In this case, at least about 200 thousand birds were killed.

If we compare the materials on catastrophic releases of petroleum fluids between the Gulf of Mexico and the Tengiz oilfield, then we have that for one day of elimination 9,138 tons of oil were thrown into the Gulf of Mexico and 8,548 tons at the Tengiz field on average. The weight amount of oil fluids emissions in both regions is approximately the same [4].

\section{Materials and methods}

Research methods: empirical (observation and comparison), theoretical (abstraction, axiomatic, analysis and deduction). 
The methodical principles of an estimation of economic damage are based on two approaches to estimation (rate) of damage from pollution of an environment: Indirect (integrated) and bu objects.

In researches applied methods ArcGIS Server component provides storage cards as a service to display in the Publish Map Web-Part.

Pre-processing Module Component allows the generation of configuration files required for the calculation of wind, hydrodynamics and oil spill.

Component Mike $21 \mathrm{HD}$ [5] provides the calculation of hydrodynamics.

\section{Component Mike 21 SA [6] calculates an oil spill.}

Risk App component calculates the probability risk of oil pollution of the sea and the destruction of biota in the Northern Caspian [7]. Storage layer comprises a database for storing information $[8,9]$. The geodynamic monitoring of the Kazakh scientists is conducted on the basis of geo-positioning space with the GPS satellites, GLONASS, accompanied by JSC "National Center for Space Research of Kazakhstan" [10,11].

\section{Results and discussion}

Currently, high sulfur giant subsalt oil and gas deposits are being developed on the Kazakhstani shelf of the Caspian Sea, which is unprecedented in the history of oil industry in Kazakhstan. It is necessary to study the mechanisms and predisposition to certain areas of catastrophic events for the prevention of possible emergency situations. The analysis shows that emergencies occur where the earth's crust accommodating giant oil reservoirs more active, not calm, tectonic shifts occur. All the pre-salt oil reservoirs represented as a "giant powder container" with abnormally high pressure, temperature and high hydrogen sulphide content (Table 1).

According to the geophysical research conducted by Western oil companies, the structure (reservoir) of oilfields Kashagan, Kayran, Aktoty, Korolevskoe and Tengiz oilfield is a single complex area, about $160 \mathrm{~km}$ long, $40 \mathrm{~km}$ wide, with some pinches. Clearly, that new deposits of hydrocarbons will be opened within this area and gas fields.

The oil reservoirs at depths of 4,000-5,500 meters are under stress, under enormous pressure in-situ 800-1,100 atm., occupying a total area of 3,154 square kilometers and water area

Table 1: Characteristics of the pre-salt oil and gas fields.

\begin{tabular}{|c|c|c|c|c|c|c|}
\hline \multirow{2}{*}{ Main Data } & \multicolumn{5}{|c|}{ Fields } \\
\cline { 2 - 7 } & Kashagan & Kairan & Aktoty & Korolevskoe & Tengiz \\
\hline $\begin{array}{c}\text { Depth, m. } \\
\text { Reservoir pressure } \\
\text { in atmospheres. }\end{array}$ & $4,000-5,500$ & $3,200-5,500$ & $3,600-5,000$ & 4,000 & $4,000-5,500$ \\
\hline $\begin{array}{c}\text { Reservoir } \\
\text { temperature, }{ }^{\circ} \mathrm{C}\end{array}$ & $110-130$ & $110-130$ & $110-130$ & $110-130$ & $110-130$ \\
\hline $\begin{array}{c}\text { The content of the } \\
\text { gray-hydrogen (H2 } \\
\text { S) }\end{array}$ & $19-22$ & $16-20$ & 22 & 16 & $19-23$ \\
\hline
\end{tabular}

of the sea coast. According to the academician the violations of moderate static state of giant oil storage tanks can trigger:

1. Natural earthquake

2. Man-made earthquakes

3. Technological violations of drilling and exploitation of the deposit.

According to the Institute of Seismology, the territory of Atyrau region, including the Caspian Sea, is related to the areas of the crust with the possible manifestations of earthquakes of magnitude 6 on the Richter scale. Right here in tectonically active areas of the Earth's crust large subsalt of oil and gas deposits are located. Modern active faults within the Tengiz field (vertical) have up to $5 \mathrm{~cm}$ per year, which was established by repeated leveling tool.

On the eastern coast of the Kazakhstani sector of the Caspian Sea at the end of April 2000, there was a large-scale subsidence of the Earth's surface. As a result of tectonic downstream movements, the huge tracts of Kalamkas and Karazhambas were flooded. More than one hundred well sites were under water. This coastline stretched for tens of kilometers.

Thus, the uncontrolled development of the huge pre-salt hydrocarbon resources of the Caspian Sea in Kazakhstani sector will be under strong natural and anthropogenic geodynamic factors. Risks of natural earthquakes are essential.

The emergence of the danger of natural and man-made earthquakes increases, because since 1993 at the Tengiz field, in a growing volume hydrocarbon resources have been extracted. Injection of water or gas to fill the voids and cracks liberated so far are not conducted. This circumstance leads to a moderate violation of the static state of the subsoil [10] leading to the following geophysical processes:

1. Fall in situ pressure on the periphery of the oil tanks.

2. Change of the phase relationship of hydrocarbon systems.

3. Change of the temperature condition of oil tanks.

Drilling of the first well at Kashagan started on 11 August 1999. In winter of 2000 , the first subsalt with huge reserves of oil and gas was opened - 38 billion of barrels, or 6 billion tons, of which there were about 10 billion recoverable barrels of oil. Our fears of the emergence of man-made earthquakes are real and it is an expected phenomenon. This is confirmed by the declaration of "Agip KCO" of intent to develop the Kashagani field, where it is noted that "... the planned development of offshore oil production on the shelf of the Northern Caspian Sea will be counted not in years, but for many decades."

A certain danger is represented by 19 deposits, which are located on the 1,485 drilled wells that are located in the zone of flooding and pre-flooding of the Caspian Sea. Some of them give a leak; very dangerous 150 wells are located in the coastal part of the sea. Too little funds are allocated to eliminate them (25 million tenge in 2009 to eliminate the 20 wells). It should 
be noted that the uniqueness of the Kashagan field, located in the shallow area of the Kazakhstani North Caspian biological resources is in rich feeding grounds, migration routes of fish and birds. According to our research, the biomass per unit area is about 1.5-2 times higher than in the rest of the sea. The particular vulnerability of the Kazakh part of the total water volume of all the sea is only $0.94 \%$ while $27.73 \%$ of the area of the entire sea area (more than 398,000 sq. $\mathrm{km}$ ), with an average depth of $6.2 \mathrm{~m}$. If you pour a ton of oil per unit volume in different parts of the sea, the lethal concentration here is achieved much faster.

The Caspian Sea has immense beauty and diversity of ecosystems and is rich in natural resources, not yet being fully investigated and is not used efficiently. The Caspian Sea has a climate formation value and is unique in that it was called the relict flora and fauna, including the world's largest herd of sturgeon fish (90\% of world reserves). The Caspian Sea is home to more than 500 species of plants and 850 species of animals. The Caspian Sea is a major migratory route and habitat for waterfowl and shorebirds.

In fact the Kazakhstan's Caspian Sea coast is lower and is very similar to the low marshy shores of Louisiana, which was hit hard by the oil spill. Here on the shores of the Caspian Sea protected wetlands are situated, and the state nature reserve "Ak Zhayik" is in front of the Kashagan field, where rare species of fish, birds and animals live. In the event of a similar disaster in the Caspian Sea, with the help of wind surges, the oil can go on the marshy coastal waters, where it will not be possible to collect it any longer. Marshy ground will easily absorb oil mixture, and the unique nature of the Caspian Sea will be lost.

Unfortunately, the pollution of the Caspian Sea continues. Only from "Tengizchevroil" LLP emission of pollutants in the atmosphere has made more than 1 million tons. Thus, one ton of crude oil accounts for 7.07-8.0 kg of harmful substances, which is based on the oxides of sulfur, nitrogen, sulfuric and nitric acids. As a result, in the eastern part of the sea water area there is a decrease in $\mathrm{pH}$. The difference between the extreme values of $\mathrm{pH}$ in the studied sea area reaches 1.59 (8.4 to 6.81) indicating the real-acidification of marine waters.

According to standard calculations, for every million tons of extracted oil in the world we have an average of 131.4 tons of losses. If on Northern the Caspian Sea is planned production of 70-100 million tons of oil that we will have losses of not less than 13 thousand tons per year. The Tengiz massive amounts of elemental sulfur, stored in the open-air form, are constant and an ever-increasing source of environmental pollution. As a result, sulfur bacteria from the surface of the sulfur arrays allocate sulfuric acid. Under the influence of contamination of oil and gas the complex disease of the population of nearby towns is $90 \%$, and the incidence of the population of the Atyrau region increased by $50 \%$, which is the result of a local environmental disaster.

The existing system of environmental monitoring and research in the Caspian Sea is cumbersome and inefficient, allowing manipulation of information and public opinion.
We offer new technology of monitoring. The information observation system will be the most flexible, decentralized and suitable for progressive public involvement in the management of natural resources. It will clearly identify the anthropogenic contribution of all charges against the background of natural processes.

1. Ensuring the balance between conservation, protection of biological resources and the conduct of petroleum operations, extraction of hydrocarbons at sea. Developing a set of measures to limit acidification of a vast area (approximately 8,000 sq. $\mathrm{km}$ ) to the east of the Caspian Sea water area and resolving issues of compensation for damage provide oil companies with the aquatic environment and bio-resources;

2. Implementation of international standards for assessing the impact of ongoing oil operations, including providing objective data on the concentrations of highly dangerous toxic pollutants, mercaptans, restrictions on in-depth development of more than 8-10 thousand meters.

3. Implementation of control over the volume withdrawn from the bowels of the earth and efficient hydrocarbon volumes injected into oil horizons of water and gases. Control to carry out the disposal of liquid industrial waste in the bowels, resulting in disrupted static condition of the subsoil;

4. Development of an emergency situation model on the shelf and eliminating them for the shortest possible time, as well as the methods of calculation for the full recovery of environmental damage to the natural environment during operations and emergency situations;

5. Providing comprehensive monitoring on modern methods of mathematical modeling, covering the most predictive indicators of ecological disaster, the legal framework of environmental protection and comprehensive planning, coastal zone management.

Today in the Kazakhstani sector of the Caspian there are performed unprecedented in scale and quantity dangerous oil and gas resources. The accelerated development of oil resources will lead to a significant loss of the quality habitat of biological resources and people.

Analyzing the scale of environmental complications, we set out to study the causes of environmental emergencies in the normal mode in the long development of oil fields. In the process of the long-term development there is the accumulation of toxic substances in the soil, the plants, the aquatic environment, sediments and internal human organs, animals, birds, fish and others. In the end, the whole ecosystem will be infected with toxicants.

According to our calculations in the future with the full development of the huge pre-salt oil resources, by schedule production the atmospheric pool and water area of the Caspian Sea Kazakhstani sector can throw out 28.0 million tons of 
poisonous substances. From these components there may be formed 9.93 million tons of sulfuric, 5.3 million tons of nitrogen and 10.45 million tons of carbonic acid, they are also the most destructive compounds of the natural environment in the world.

Despite the shallow waters of the Kazakhstani sector sea company Eni SpA with the operator "Agip Caspian Sea BV" plans in the future to increase production levels from 55.8 to $98.0 \mathrm{mln}$ tons of oil per year. Contract area under the North Caspian Sea PSA includes the giant Kashagan oil field which is the first major offshore field in the Republic of Kazakhstan, as well as the fields of Kashagan Southwest, Aktoty, Kayran and Kalamkas. The scope and complexity of the operations carried out by a consortium of persons, which includes the companies: Eni, Shell, Exxon Mobille, Total, ConocoPhillips, KMG, and INPEX which are aware that such production rates can lead to irreversible processes i.e. radical destruction of the ecosystem of the North Caspian.

The study area is under the influence of regional compression. The fractures in the upper layers of the crust under a layer of sedimentary rocks are at depths of 4-12 km in areas of hydrocarbon production, which increases the risk of man-made disasters. In developing the Tengiz field in the last eight years tons of crude oil was released into the atmospheric pool in the average $4.99 \mathrm{~kg}$ of toxic substances at the design 2.0-2.5 kg. From poisonous substances there is emitted the amount of $1.33 \mathrm{~kg}$ of sulfur and $0.69 \mathrm{~kg}$ of nitrous gases which are defined as the most damaging ecosystems gases. On the industrial sites of Tengiz, only in 2007-2010, there were more than 160 accidents followed by burning and sour raw gas to the flare.

The aquatic resources suffer so for many years in the drainage wells and other technological nodes of the islands of Kayran and Aktoty, more than 700 dead birds have been found. With such a disparaging approach the foreign oil companies should expect further environmental complications. Aadmittedly saying, the signing of many environmental and legal issues missed contracts, including stringent penalties and insurance in case of an environmental disaster [12].

As a result of long and intensive exploitation of the oil field, the critical situation for the environment comes without doubt; however, to justify and determine the time of occurrence of such a situation is not an easy task. The authors of this article have attempted to solve it.

Criteria for evaluating the forecast anthropogenic loads. Estimates of future emissions into the atmosphere have been made on the basis of multi-year reached actual emissions into the air of toxic substances per ton of crude oil (an average of 4.0 kg per 1 ton of harmful substances.) by various oil companies.

"Tengizchevroil" LLP mined in 2009-2015 178.5 million tons of salt oil, and there was released into the atmosphere 887.8 thousand tons of toxic substances or $4.99 \mathrm{~kg}$ of toxic substances per ton of oil were produced, as in 2001-2008 per ton of oil emissions amounted to $3.95 \mathrm{~kg}$ of toxic substances.
Critical anthropogenic impact on the environment. Anthropogenic impact on the environment is determined from the analysis of the health of the inhabitants of the village Sarkamys located $12-15 \mathrm{~km}$ from the sanitary protection zone of the Tengiz field. The average volume of emissions for these years amounted to 604.2 thousand tons, while the production of "Tengizchevroil" LLP was 98.2 million tons of oil.

Growth of dynamics of critical loads at different levels of production and timing of development of pre-salt oil. We calculated the possible dynamics of critical load exceeding ( 0.8 million tons of emissions) at the timing of the development of 10 to 50 years with an interval of five years and production volumes in $15,20,25,30,35,40,45,50,55,60,70,80,90$ and 100 million tons of oil. For the calculation of the average specific emissions of 4, 3 and $2 \mathrm{~kg}$ per 1 ton were adopted.

We obtained the following results. When reaching $4.0 \mathrm{~kg}$ of emissions per 1 ton of the produced oil exceeding the critical load from 0.75 to 25 times in terms of the development of 10 to 50 years it makes up 15-100 million tons of production volumes a year. When possible $2.0 \mathrm{~kg}$ of emissions into the pool exceed the critical load, they are 0.37-12.5 times under the same terms of development and production volumes. We have divided Harmful effects on the environment into zones (stages).

I. If possible $4.0 \mathrm{~kg}$ of emissions of hazardous substances per 1 ton crude oil take place (Figures 1,2), the following sequence was obtained:

The third zone (stage). The zone of intensive environmental disasters. Extraction of 2.65-4.0 billion tons of oil. Emissions into the atmospheric pool subsalt oil of $8.0-12$ million tons. Of this amount there could be formed 2.2-4.8 million tons of sulfuric acid and 1.5-2.3 million tons of nitric acid.

The second zone (stage). Zone of ecological disasters. Zone of 1.3-2.65 billion tons of oil. Emissions of subsalt oil of 4.08.0 million tons of poisonous substances. Of this amount there could be formed 1.6-2.2 million tons of sulfuric acid and 0.751.5 million tons of nitric acid

The first zone (stage). The difficult situation is critical in the environment on the verge of the ecological disaster. The volume of oil production of 1.3 billion tons. Emissions into the atmospheric pool of 4.0 million tons. Of this amount 1.6 million tons there could be formed sulfuric acid and 0.75 million tons of nitric acid.

The fourth zone (stage). The zone strengths of environmental disasters. Extraction of 3.0-4.0 billion tons of oil. Emissions into the atmospheric pool of 12-16 million tons of toxic substances. Of this amount there could be formed 4.86.4 million tons of acid and $2.26-3.028$ of nitric acid.

The third zone (stage). The zone of intensive environmental disasters. Extraction of 2.0-3.0 billion tons of oil. Emissions to the atmosphere of toxic substances Pool of 8-12 million tons. Of this amount of the substances there could be formed 3.2-4.8 million tons of sulfuric acid and 1.5-2.3 million tons of nitric acid. 



Figure 1: The degree of changes in the environment depending on the volume of oil production and timing of development of deposits.

The second zone (stage).The zone of ecological disasters .Mining of 1.0-2.0 billion tons of oil .Emissions into the atmospheric pool of 4.0-8.0 million tons of poisonous substances. There could be formed 1.7-3.2 million tons of sulfuric acid and 0.7-1.5 million tons of nitric acid.

The first zone (stage). The difficult situation is critical in the environment on the verge of the ecological disaster. From the production of 1.0 billion tons of oil there are emissions of 4.0 million tons of pool toxic substances, the development of pre-salt oil: of them there could be formed 1.6 million tons of sulfuric acid and 0.75 million tons of nitric acid.

The first zone (stage). Environmental complications on the verge of emergencies can occur when the total production of subsalt oil is $0.5-1.0$ billion tons and the release into the atmosphere of 4.0 million tons of toxic substances is a 5 -fold excess of critical loads.

The second zone (stage) of environmental emergencies occur in the extraction of 1.0-2.0 billion tons of oil and emissions of the pool of 4.0-8.0 million tons of toxic substances, which is a ten-fold excess of the critical loads of the anthropogenic impact.

The third zone (stage) of the intensive ecological disasters occurs in the extraction of 2.0-3.0 billion tons of oil and emissions of 12.8 million tons of toxic substances, which is 15 fold excess of the critical loads of the anthropogenic impact.

The fourth zone (stage) of environmental disasters occurs in the extraction of 3.0-4.0 billion tons of oil and emissions of the pool of 12.0-16.0 million tons of toxic substances, which is 20-fold excess of the critical loads of the anthropogenic impact.

II. Upon reaching $3.0 \mathrm{~kg}$ of emissions of pollutants per ton of oil produced (Table 2) is formed:

The first zone (stage) on the verge of complications of environmental disasters occurs in the production of $0.5-1.3$ billion tons of oil and the release into the air of 4.0 million tons of toxic substances, which is 5 -fold excess of the critical loads of the anthropogenic impact.

The second zone (stage) of environmental disasters occurs 

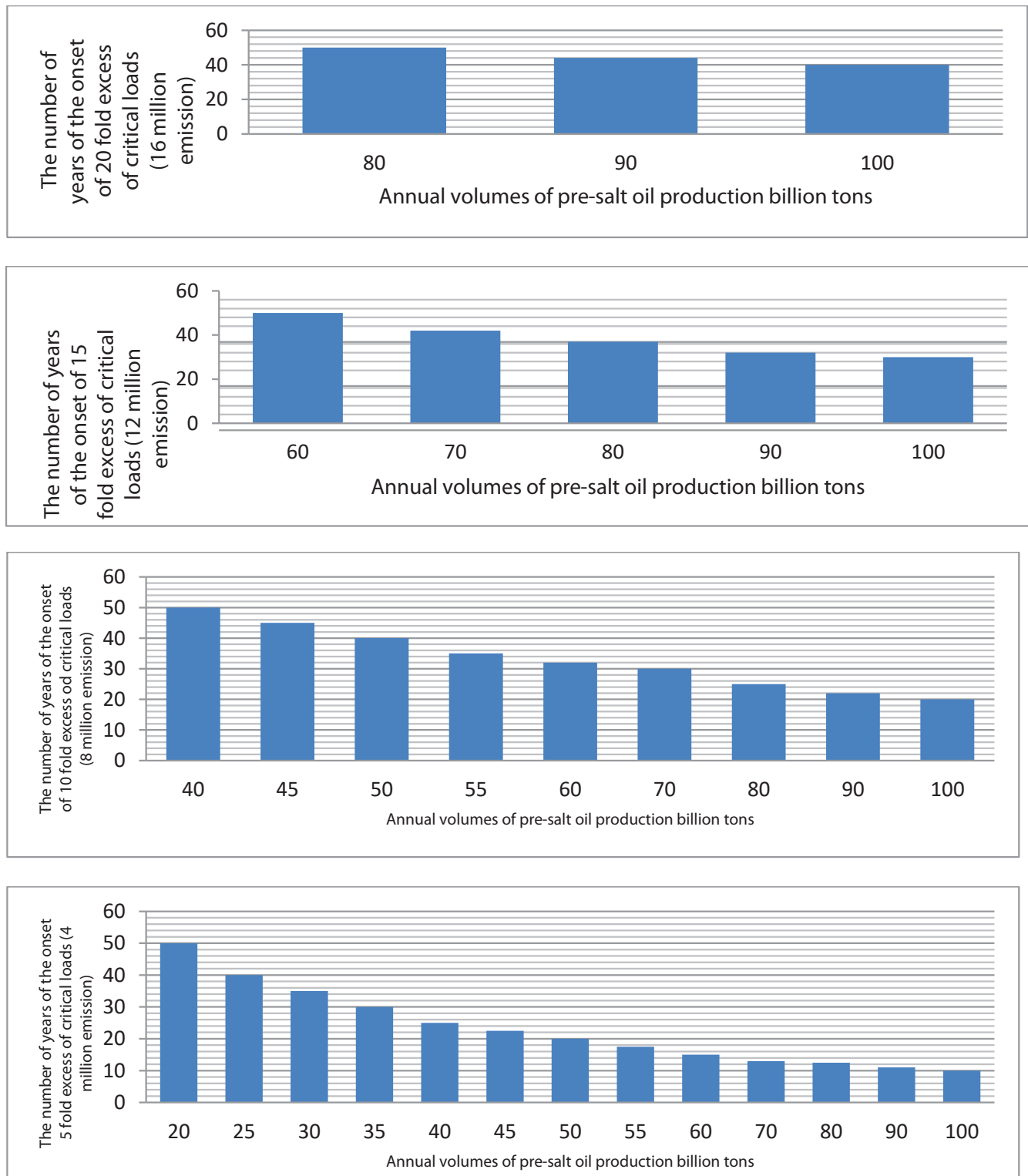

Figure 2: The degree of changes in the environment depending on the volume of oil production and timing of development of deposits.

in the production of 1.3-2.65 billion tons of oil will give the release into the air of 4.0-8.0 million tons of toxic substances, which are 10-fold excess loads.

The third zone (stage) includes intensive ecological disasters. They will come when the production of $2.65-4.0$ billion tons of oil will give the release into the air of 8.0-12.0 million tons of toxic substances, which is 15 -fold excess of the critical loads of the anthropogenic impact.

The next task was to calculate the dynamics of the growth of harmful emissions into the pool at different levels of oil production and timing of the development of deposits. Calculations of the total volume of emissions into the pool at the development of offshore oil fields for 50 years with an interval of 5 years, and annual production volume of 15 to 100 million tons of oil. The main criteria of progress $(4 \mathrm{~kg})$ were taken for calculating emissions during the production and the potential in the long term ( $3 \mathrm{~kg}$ and $2 \mathrm{~kg}$ ) of emissions per ton of the produced oil companies. We obtained the following results.

Under the specific emissions of $4 \mathrm{~kg}$ per 1 ton produced oil. Total emissions in the atmosphere during the annual volume of $15-100$ million tons of production per year, for $10,20,30,35,40,45,50$ years there were $0.6-20$ million tons of poisonous substances.

Under the specific emissions of $3 \mathrm{~kg}$ per 1 ton produced oil. Total emissions of the pool at the same annual volumes of oil production and for 10 to 50 years accounted for Mt 0.45-15 poisonous substances.

Under the specific emissions of $2 \mathrm{~kg}$ per 1 ton produced oil. Total emissions in the atmosphere under the same annual oil production of $15-100$ million tons per year, for 10 to 50 years 
make up 0.3-10 million tons for the estimated time of occurrence of environmental disasters and various complications (Table 2), depending on the volume of production and timing of the development of deposits.

From Table 2 it is clear that the environmental catastrophe on the verge of complications occurs in 10 years at 100 million tons of annual crude oil production.

Environmental limits of the development of pre-salt oil reserves. In the development of pre-salt oil resources of the Caspian Sea shelf there may be two alternatives (catastrophic and science-based).

1. It is technically possible to pump all the oil from the bowels of the sea without regard to their disastrous consequences rapidly.

2. The development of hydrocarbon resources to conduct

Table 2: The onset of complications and environmental disasters, depending on the annual production and development period with normal mode.

\begin{tabular}{|c|c|c|c|c|}
\hline \multirow{2}{*}{ Stage of complications } & $\begin{array}{l}\text { Time of } \\
\text { onset, } \\
\text { through } \\
\text { years }\end{array}$ & \begin{tabular}{|c|} 
Annual \\
production \\
volume, $\mathrm{mln}$ \\
tons
\end{tabular} & $\begin{array}{l}\text { Time of } \\
\text { onset, } \\
\text { through } \\
\text { years }\end{array}$ & $\begin{array}{c}\text { Annual } \\
\text { production } \\
\text { volume, } \mathrm{mln} \\
\text { tons }\end{array}$ \\
\hline & \multicolumn{2}{|c|}{$\begin{array}{l}\text { A. In fact, specific } \\
\text { emissions per ton of } \\
\text { crude oil } 4.0 \mathrm{~kg}\end{array}$} & \multicolumn{2}{|c|}{$\begin{array}{l}\text { B. Possible specific } \\
\text { emissions per ton of } \\
\text { crude oil } 3.0 \mathrm{~kg}\end{array}$} \\
\hline \multirow{13}{*}{$\begin{array}{l}\text { Environmental complications } \\
\text { on the brink of disaster. Total } \\
\text { emissions of } 4.0 \text { million tons } 5 \\
\text { times exceeding critical loads }\end{array}$} & 10 & 100 & 13 & 100 \\
\hline & 11 & 90 & 15 & 90 \\
\hline & 12.5 & 80 & 17 & 80 \\
\hline & 13.0 & 70 & 19 & 70 \\
\hline & 15 & 60 & 22 & 60 \\
\hline & 17.5 & 55 & 24 & 55 \\
\hline & 20 & 50 & 25 & 50 \\
\hline & 22.5 & 45 & 30 & 45 \\
\hline & 25 & 40 & 33 & 40 \\
\hline & 30 & 35 & 38 & 35 \\
\hline & 35 & 30 & 44 & 30 \\
\hline & 40 & 25 & 53 & 25 \\
\hline & 50 & 20 & 61 & 20 \\
\hline \multirow{10}{*}{$\begin{array}{l}\text { Ecological disasters. Emissions } \\
\text { of } 8.0 \text { million tons } 10 \text { times } \\
\text { exceeding critical loads }\end{array}$} & 20 & 100 & 27 & 100 \\
\hline & 22 & 90 & 30 & 90 \\
\hline & 25 & 80 & 33 & 80 \\
\hline & 30 & 70 & 38 & 70 \\
\hline & 32 & 60 & 45 & 60 \\
\hline & 35 & 55 & 48 & 55 \\
\hline & 40 & 50 & 53 & 50 \\
\hline & 45 & 45 & 59 & 45 \\
\hline & 50 & 40 & 66 & 40 \\
\hline & 67 & 30 & 69 & 30 \\
\hline \multirow{6}{*}{$\begin{array}{c}\text { Intensive environmental } \\
\text { disasters. Emissions of } 12.0 \\
\text { million tons } 15 \text { times exceeding } \\
\text { critical loads }\end{array}$} & 30 & 100 & 40 & 100 \\
\hline & 32 & 90 & 45 & 90 \\
\hline & 37 & 80 & 50 & 80 \\
\hline & 42 & 70 & 58 & 70 \\
\hline & 50 & 60 & 67 & 60 \\
\hline & 60 & 50 & 80 & 50 \\
\hline \multirow{6}{*}{$\begin{array}{c}\text { Extreme environmental } \\
\text { disasters. Emissions of } 162.0 \\
\text { million tons } 20 \text { times exceeding } \\
\text { critical loads }\end{array}$} & 40 & 100 & 53 & 100 \\
\hline & 44 & 90 & 59 & 90 \\
\hline & 50 & 80 & 67 & 80 \\
\hline & 57 & 70 & 76 & 70 \\
\hline & 67 & 60 & 89 & 60 \\
\hline & 80 & 50 & 107 & 50 \\
\hline
\end{tabular}

the science-based rate, preserving the ecosystem of the Caspian Sea basin in a satisfactory condition.

We have established the dependence of the time of occurrence of complications and the environmental disasters on the exceeding of critical environmental loads ( 0.8 million tons of emissions into the air) while maintaining planned volumes of production of subsalt oil on Tengiz and Kashagan. So the Kashagan field development in the period of industrial development is planned to produce 21.0 million tons of oil, 24 million tons produced at Tengiz.

For the calculation we passed the total annual level of 50 million tons of production of oil. At the same time, according to our calculations, the advance environmental complications on the brink of disasters with the actual specific emissions of $4.0 \mathrm{~kg}$ per 1 ton of crude oil amounted to a period of 20 years (Table 2), environmental disasters - 40 years, intensive environmental disasters -60 years.

Evidence-based (recommended) annual production volume of subsalt oil on Tengiz and Kashagan. To solve the problem, we found the number of emissions into the atmosphere pool with the annual production of subsalt oil from 100 to 15 million tons at intervals of $5 \mathrm{mln}$ tons for 50 years. It turned out that the expected atmospheric load greatly exceeds the critical pool.

On the basis of submissions received, we consider it possible to produce the annual pre-salt oil with high content of sulfur oxides, nitrogen and other toxic substances for Tengiz deposits - 15 million tons per year, and the same for Kashagan (15 million tons per year). The recommended total amount of oil should be between 30 million tons a year.

According to our data the estimated time at the onset of the actual level of $4.0 \mathrm{~kg}$ of toxic substances into the air per ton of crude oil produced and the total annual production of 30 million tons of subsalt oil, environmental complications can be expected on the brink of the disaster in 35 years, as an ecological disaster over 67 years.

With the development of pre-salt oil resources, in any case, expected environmental disasters, it is only a matter of time. If you develop at an accelerated pace, the catastrophe will come earlier; if slowly, then the catastrophes will be much later, i.e., a few decades later.

With the development of pre-salt resources of the sea there can be several stages of the loss of quality of the environment. For example, an ecosystem suitable for human life will maintain with the withdrawal from the sea subsoil of 0.5-1.0 billion tons of subsalt oil, which may be accompanied by environmental complications on the brink of the catastrophes.

The natural environment is very suitable for human life (transition period) and it is possible in the extraction of 1.0-2.0 billion tons of oil, with a probability of environmental disaster.

The natural environment on the quality of air, water, soil not suitable for human life (like Chernobyl) is expected at the withdrawal from the depths of the sea of 2.0-3.0 bln tons of 
pre-salt oil. This tragedy will be accompanied by intensive environmental disasters, and the seizure of 3.0-4.0 billion tons from the depths of the sea-salt oil will cause extreme environmental disasters. And the worst thing is to happen at the withdrawal from the bowels of 4.0-5.0 billion tons when there will be a very strong environmental disaster.

Thus, from the huge subsalt resources of BMSC it is possible to master with environmental complications on the brink of the disaster just $0.5-1.0$ billion tons from 7.0 billion tons of oil approved and registered by the recoverable resources of pre-salt oil, which makes up only $8.0-15 \%$ of all reserves of industrial resources of the pre-salt oil.

In order to improve the environmental situation and to ensure the highest possible volume of pre-salt oil, we recommend as follows:

- On the Tengiz fieled - the annual volume of the produced pre-salt oil should not exceed 15 million tons per year. The first generation plant must be shut down for reconstruction or finally. The associated gas in full should be pumped back into the underground horizons.

- On the Kashagan field - the annual volume of the produced pre-salt oil should not exceed $\mathbf{1 5 . 0}$ million tons per year. About $80 \%$ of the associated gas volumes without treatment should be pumped back into the tanks.

Foreign oil companies and the Government of the Republic of Kazakhstan should understand that the massive development of the enormous hydrocarbon resources in the pre-salt deposits in the Kazakhstani sector of the Caspian Sea will lead to the inevitable environmental and technological disasters. That entails the loss of billions of dollars invested in the development of resource deposits with the stop and conservation of many acting manufactures and infrastructures.

This bitter experience concerned the developments in Russia during the development of gas condensate field of Aksaraisk of the Astrakhan Arch at the end of the 80s of the last century. Now from the initial production volumes withdrawn from the depths there are only a quarter of that and had significant impacts on the environment.

Our task is to warn about the possible complications and the environmental impact of the disaster during the development of oil resources of the Caspian Sea oil fields [4]. We should point out the scientifically based (recommended) annual volumes of production of subsalt oil on Tengiz and Kashagan.

There should be noted the uniqueness of the Kashagan field located in the shallow area of the Kazakhstani North Caspian with its biological resources and rich feeding grounds on the migration routes of fish and birds. According to our research, the biomass per unit area is about 1.5-2 times higher than in the rest of the sea. The particular vulnerability of the Kazakhstani part of the total water volume of all the sea is only $0.94 \%$ with the area of $27.73 \%$ of the entire sea area (more than 398,000 sq. km), with an average depth of $6.2 \mathrm{~m}$. If you pour a ton of oil per unit volume in different parts of the sea, the lethal concentration here is achieved much faster.
This requires careful respect for the sea, the maintenance of its biological resources and preventive measures against future mass diseases and poisoning of every living thing [4].

\section{Conclusion}

In spite of the unique biological resources and the danger of large-scale oil operations the largest countris in the world (the USA, England, France, Italy, Russia, China) and Kazakhstan are interested in the long-term development of oil fields in the Caspian Sea shelf.

If Government does not organize an independent working group of scientists and specialists on Integrated Monitoring, early (maybe next year) or late in the Kazakhstani part of the Caspian Sea catastrophic oil and gas emissions may occur. For their elimination it will be required from two to several months. In the future, the cycle of "drilling, oil and gas extraction + catastrophic elimination of emissions + production" will be repeated. After each cycle the sea water toxicity will increase and become more dangerous to the environment [4].

Environmental disasters occurring in the Caspian Sea will have the interstate resonance. With this, migratory, nesting and wintering birds of the sea area, in total more than 10 million, will be affected and some will die. A significant part of migrating will spread the disease in many waters, seas and continents of the globe. The process will be permanent. As a result of these accidents, toxic clouds of the contaminated sea water will rise into the upper atmosphere to the ozone layer of the earth and the air flow will transfer considerable space to form acid rain, destroying forests, grasslands and many components of the environment.

\section{References}

1. Ogar NP, Geldyev BV, Maksimov MA (2014) Overall environmental features of the North-Eastern Caspian Sea. Environmental Monitoring of the natura environment of the North-East Caspian Sea during Development of Oil Fields. Almaty $12-28$

2. Shivareva SP, Ivkina NI (2000) Kaspyiskoe more u beregov Kazakhstana Cas pian Sea of Kazakhstan coasts 25

3. K Sh F, Asanbaev IK, Abdukajmova AM (2005) Sovremennye problemy zagryazneniya pochv neftepromyslov prikaspiya Neft i gaz [Modern problems of soil pollution of the Caspian oil fields Oil and gas 62-68.

4. Diarov MD (2006) Ecology and oil and gas complex: Monogr. / Atyraus. Institute of oil and gas - Almaty: Evero - 54-672.

5. DHI Software 2008 MIKE 21 HD Hydrodynamic Model User Guide106.

6. DHI Software 2008 MIKE 21 \& MIKE 3 PA/SAParticle analysis and oil spill analysis module User guide108.

7. Bostanbekov KA, Jamalov JK, Kim DK, Nurseitov DB, Tursunov IE, et al. (2013) Integrated workflow-based system for risk mapping of oil spills with using high performance cluster. International Journal of New Computer Architectures and their Applications (IJNCAA) 3: 115-131. Link: https://bit.ly/3Fnp39e

8. Bostanbekov KA, Jamalov JK, Kim DK, Nurseitov DB, Tursunov IE, et al (2013) Service-Oriented GIS System for Risk Mapping of Oil Spills Integrated with High Performance Cluster The Second International Conference on Informatics Engineering \& Information Science (ICIEIS2013) 343-354. Link: https://bit.ly/3AfTbzF 
9. Bostanbekov K, Nurseitov D (2016) The Development of Risk Assessment System for Accidental Oil Spill in the Northern Caspian Sea. Computer Modeling \& New Technologies. 20: 35-41. Link: https://bit.ly/3Bun0xT

10. Zhumagulov BT (2004) Simulation of oil displacement in view of mass transfer processes. Almaty 187.

11. Zhantaev ZS, Breusov NG (2011) The role of space technology in ensuring security in the extraction of hydrocarbons in Kazakhstan. / materials of the
International Conference: "Space for the benefit of mankind is a look into the future", Astana 41-42

12. Nurushev M, Diarov M, Nurgaliyeva Z, Samatova I, Bakeshova Zh (2010) Scientific basis for efficient prevention and elimination of disastrous oiland-gas emissions in Kazakhstan sector of the Caspian Sea. Internationaler Kongress Fachmesse: Okologische, Technologische und Rechtliche Aspekte dtr Lebensversorgung. Hannover 79-80.
Discover a bigger Impact and Visibility of your article publication with

\section{Peertechz Publications}

\section{Highlights}

* Signatory publisher of ORCID

* Signatory Publisher of DORA (San Francisco Declaration on Research Assessment)

* Articles archived in worlds' renowned service providers such as Portico, CNKI, AGRIS, TDNet, Base (Bielefeld University Library), CrossRef, Scilit, J-Gate etc.

* Journals indexed in ICMJE, SHERPA/ROMEO, Google Scholar etc.

* OAI-PMH (Open Archives Initiative Protocol for Metadata Harvesting)

* Dedicated Editorial Board for every journal

* Accurate and rapid peer-review process

* Increased citations of published articles through promotions

* Reduced timeline for article publication

Submit your articles and experience a new surge in publication services (https://www.peertechz.com/submission).

Peertechz journals wishes everlasting success in your every endeavours. 